\title{
NUMERICAL SIMULATION OF HYDRODYNAMICS AND HEAT TRANSFER PROCESSES IN ROTOR-PULSING APPARATUS FOR PREPARATION OF LIQUID FEED
}

\author{
V.G. Gorobets, doctor of technical sciences, associate professor \\ V. I. Trokhaniak, candidate of technical sciences, associate professor \\ A. M. Serdyuk, graduate student \\ National university of life and environmental sciences of Ukraine \\ E-mail: gorobetsv@ukr.net
}

\begin{abstract}
One of the topical directions of development of the agro-industrial complex of Ukraine is the development of the pig-breeding industry of animal husbandry. The crucial role is played by the process of feeding animals. It is important to develop new designs of apparatus for the preparation of liquid feed based on grain mixtures.

The purpose of research is numerical study of the processes of hydrodynamics and heat transfer in the rotary-pulsating apparatus in the treatment of a water-grain mixture for the preparation of liquid feeds.

The mathematical modeling of the processes of hydrodynamics and heat transfer in the channels of the rotary pulsation apparatus for the preparation of liquid feeds is carried out. The numerical simulation of heat and hydrodynamic processes using the ANSYS Fluent software obtained velocity, pressure, and temperature distributions in the rotor-stator channels. The transformation of the kinetic energy of rotation of the rotor into heat energy is found, which leads to an increase in the temperature of the liquid grain mixture.
\end{abstract}

Key words: rotary pulsation device, channel, rotor, stator, pressure, speed, temperature

Topicality. One of the topical directions of development of the agro-industrial complex of Ukraine is the development of the pig-breeding industry of animal husbandry. The crucial role is played by the process of feeding animals. The current state of affairs in this area is based on the use of dry fodder. Devices using percussion mechanisms are used to prepare such feeds, such as hammer crushers, auger mechanisms, etc. Such devices require a large amount of energy, have large dimensions and mass. At the same time, it is known that when using pig livestock it is more efficient to use liquid feed for feeding. Liquid feeds are more responsive to the 
physiological needs of pigs, primarily piglets than dry ones. Moreover, the components that are part of the liquid diet (cereal grains, dairy products) contain lactic acid bacteria that ferment the feed mixture, reducing its $p h$, thereby providing a preserving effect. The advantages of including liquid feed in the diet of young animals are: 1) a much higher level of eating compared to dry feed (5\% or more); 2 ) reducing your conversion rate (up to 10\%) 3) increase in weight gain to $(6 \%)$; 4 ) the earliest possible attainment of slaughtering live weight. Therefore, it is important to develop new designs of apparatus for the preparation of liquid feed based on grain mixtures.

Analysis of recent research and publications. One of the promising areas is the development of rotary pulsation apparates (RPA) based on the principle of discretepulse energy input (DPEI). The use of such technologies makes it possible to carry out the process of grinding, mixing, dissolving feed components with simultaneous heating of liquid mass and a number of other processes [1,2]. A number of authors [3,4] have developed equipment for the preparation of homogeneous substances for various purposes - baby food, pharmaceuticals, food pastes, etc. The basic DPEI mechanisms are implemented in the preparation of these products: the effects of turbulence, cavitation, explosive boiling mechanisms and other hydrodynamic and thermal effects, which increase the quality of production and reduce energy costs for its production.

RPA for the preparation of liquid feed differs from the known fact that along with the mixing processes are the processes of grinding grain components in the liquid mixture. The degree of grinding of grain feeds significantly affects the digestibility and absorption of nutrients of the diet. The traditional method of preparation of liquid feeds with autonomous grinding of cereals and mixing with water makes it impossible to obtain feed with a degree of grinding grain of 300-500 microns, which is optimal for assimilation by animals. The technology of obtaining liquid feeds using DPEI involves mixing water with solid feed components - cereals, compound feeds, premixes, etc. The resulting mixture is processed in RPA to obtain a liquid feed with a particle size of 300$500 \mu \mathrm{m}$ [5]. Thus, the numerical and experimental study of the processes of preparation of liquid grain feeds occurring in the rotary pulsation apparatus is relevant and needs further study. 
The purpose of research is numerical study of the processes of hydrodynamics and heat transfer in the rotary-pulsating apparatus in the treatment of a water-grain mixture for the preparation of liquid feeds.

Materials and methods of research. Structurally, RPA is two coaxial cylinders a fixed stator and a movable rotor, which have radial openings on the side walls (Fig. 1). The holes may have different geometric shapes. The most common are rectangular and circular holes.

The treated substance is fed from the hopper into the rotor cavity, passes through the channels into the outlet chamber and is removed from the apparatus through pipelines. In the radial gap between the rotor and the stator there are significant shear stresses that cause dissipation of the mechanical energy of rotation of the rotor, accompanied by processes of turbulence, cavitation and lead to the heating of the fluid mixture, which reduces energy consumption for the preparation of feed.

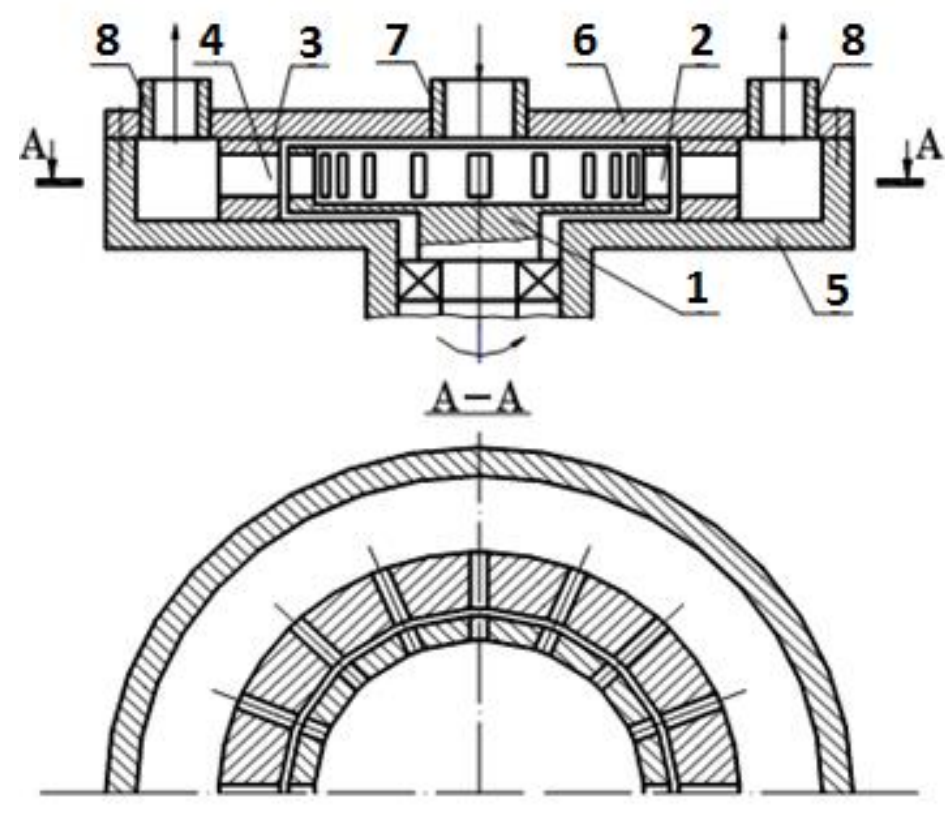

Fig.1 Scheme of the rotary-pulsating apparatus:

1 - rotor, 2 - rotor channels, 3 - stator, 4 - stator channels; 5 - housing, 6 - cover, 7 inlet; 8 - outlet

Numerical computer simulation of heat exchange and hydrodynamics processes of the studied channels of the rotor-stator system with rectangular openings based on finite element method using ANSYS Fluent software. The mathematical model of the heat and mass transfer processes occurring in the investigated RPA in three-dimensional 
formulation includes the Navier-Stokes equation system, the energy transfer equation for convective flows [6,7], and the standard $k-\varepsilon$ turbulence model [8]. The equations of convective mass and energy transfer can be expressed as

$$
\begin{gathered}
\frac{\partial \rho w_{x}}{\partial \tau}+w_{x} \frac{\partial \rho w_{x}}{\partial x}+w_{y} \frac{\partial \rho w_{x}}{\partial y}+w_{z} \frac{\partial \rho w_{x}}{\partial z}=-\frac{\partial p}{\partial x}+\frac{\partial}{\partial x}\left(\mu_{e f} \frac{\partial w_{x}}{\partial x}\right)+\frac{\partial}{\partial y}\left(\mu_{e f} \frac{\partial w_{x}}{\partial y}\right)+\frac{\partial}{\partial z}\left(\mu_{e f} \frac{\partial w_{x}}{\partial z}\right) \\
\frac{\partial \rho w_{y}}{\partial \tau}+w_{x} \frac{\partial \rho w_{y}}{\partial x}+w_{y} \frac{\partial \rho w_{y}}{\partial y}+w_{z} \frac{\partial \rho w_{y}}{\partial z}=-\frac{\partial p}{\partial y}+\frac{\partial}{\partial x}\left(\mu_{e f} \frac{\partial w_{y}}{\partial x}\right)+\frac{\partial}{\partial y}\left(\mu_{e f} \frac{\partial w_{y}}{\partial y}\right)+\frac{\partial}{\partial z}\left(\mu_{e f} \frac{\partial w_{y}}{\partial z}\right), \\
\frac{\partial \rho w_{z}}{\partial \tau}+w_{x} \frac{\partial \rho w_{z}}{\partial x}+w_{y} \frac{\partial \rho w_{z}}{\partial y}+w_{z} \frac{\partial \rho w_{z}}{\partial z}=-\frac{\partial p}{\partial z}+\frac{\partial}{\partial x}\left(\mu_{e f} \frac{\partial w_{z}}{\partial x}\right)+\frac{\partial}{\partial y}\left(\mu_{e f} \frac{\partial w_{z}}{\partial y}\right)+\frac{\partial}{\partial z}\left(\mu_{e f} \frac{\partial w_{z}}{\partial z}\right) \\
\frac{\partial \rho}{\partial \tau}+\frac{\partial \rho w_{x}}{\partial x}+\frac{\partial \rho w_{y}}{\partial y}+\frac{\partial \rho w_{z}}{\partial z}=0 \\
\frac{\partial t}{\partial \tau}+w_{x} \frac{\partial t}{\partial x}+w_{y} \frac{\partial t}{\partial y}+w_{z} \frac{\partial t}{\partial z}=\frac{1}{\rho c_{p}} \frac{\partial}{\partial x}\left(\lambda_{e f} \frac{\partial t}{\partial x}\right)+\frac{1}{\rho c_{p}} \frac{\partial}{\partial y}\left(\lambda_{e f} \frac{\partial t}{\partial y}\right)+\frac{1}{\rho c_{p}} \frac{\partial}{\partial z}\left(\lambda_{e f} \frac{\partial t}{\partial z}\right)
\end{gathered}
$$

A two-parameter standard model consisting of two differential equations of kinetic energy transfer and dissipation rate is used to model the turbulent flow

$$
\begin{aligned}
& \frac{\partial \rho k}{\partial \tau}+w_{x} \frac{\partial \rho k}{\partial x}+w_{y} \frac{\partial \rho k}{\partial y}+w_{z} \frac{\partial \rho k}{\partial z}=\frac{\partial}{\partial x}\left(\frac{\mu_{e f}}{\sigma_{k}} \frac{\partial k}{\partial x}\right)+\frac{\partial}{\partial y}\left(\frac{\mu_{e f}}{\sigma_{k}} \frac{\partial k}{\partial y}\right)+\frac{\partial}{\partial z}\left(\frac{\mu_{e f}}{\sigma_{k}} \frac{\partial k}{\partial z}\right)+G_{k}-\rho \varepsilon, \\
& \frac{\partial \rho \varepsilon}{\partial \tau}+w_{x} \frac{\partial \rho \varepsilon}{\partial x}+w_{y} \frac{\partial \rho \varepsilon}{\partial y}+w_{z} \frac{\partial \rho \varepsilon}{\partial z}=\frac{\partial}{\partial x}\left(\frac{\mu_{e f}}{\sigma_{\varepsilon}} \frac{\partial \varepsilon}{\partial x}\right)+\frac{\partial}{\partial y}\left(\frac{\mu_{e f}}{\sigma_{\varepsilon}} \frac{\partial \varepsilon}{\partial y}\right)+\frac{\partial}{\partial z}\left(\frac{\mu_{e f}}{\sigma_{\varepsilon}} \frac{\partial \varepsilon}{\partial z}\right)+c_{\varepsilon 1} G_{k} \frac{\varepsilon}{k}-c_{\varepsilon 2} \rho \frac{\varepsilon^{2}}{k}, \\
& \mu_{e f}=\mu+\mu_{t}, \lambda_{e f}=\lambda+\lambda_{t}, \mu_{t}=\frac{c_{\mu} \rho k^{2}}{\varepsilon}, G_{k}=\mu+\frac{\partial w_{x}}{\partial x_{i}}\left(\frac{\partial w_{j}}{\partial x_{i}}+\frac{\partial w_{i}}{\partial x_{j}}\right), \\
& c_{\mu}=0.09, c_{\varepsilon 1}=1.44, c_{\varepsilon 2}=1.92, \sigma_{k}=1, \sigma_{\varepsilon}=1.3 .
\end{aligned}
$$

The boundary conditions take the following form

$$
w_{i}(\tau=0)=0, w_{i}(x=0)=w_{i n}, w_{i}\left(x_{i}=x_{w}\right)=0,\left.t\right|_{s}=\left.t_{w}\right|_{s}
$$

Results of research and their discussion. This paper deals with the computer simulation of the processes of hydrodynamics and heat exchange that occur in the channels of the investigated RPA. The purpose of these calculations is to obtain local distributions of velocities, temperatures and pressures. The geometry of the channels in the rotor-stator system is shown in Fig. 1. The results of the calculations are shown in Fig. 2-4. 

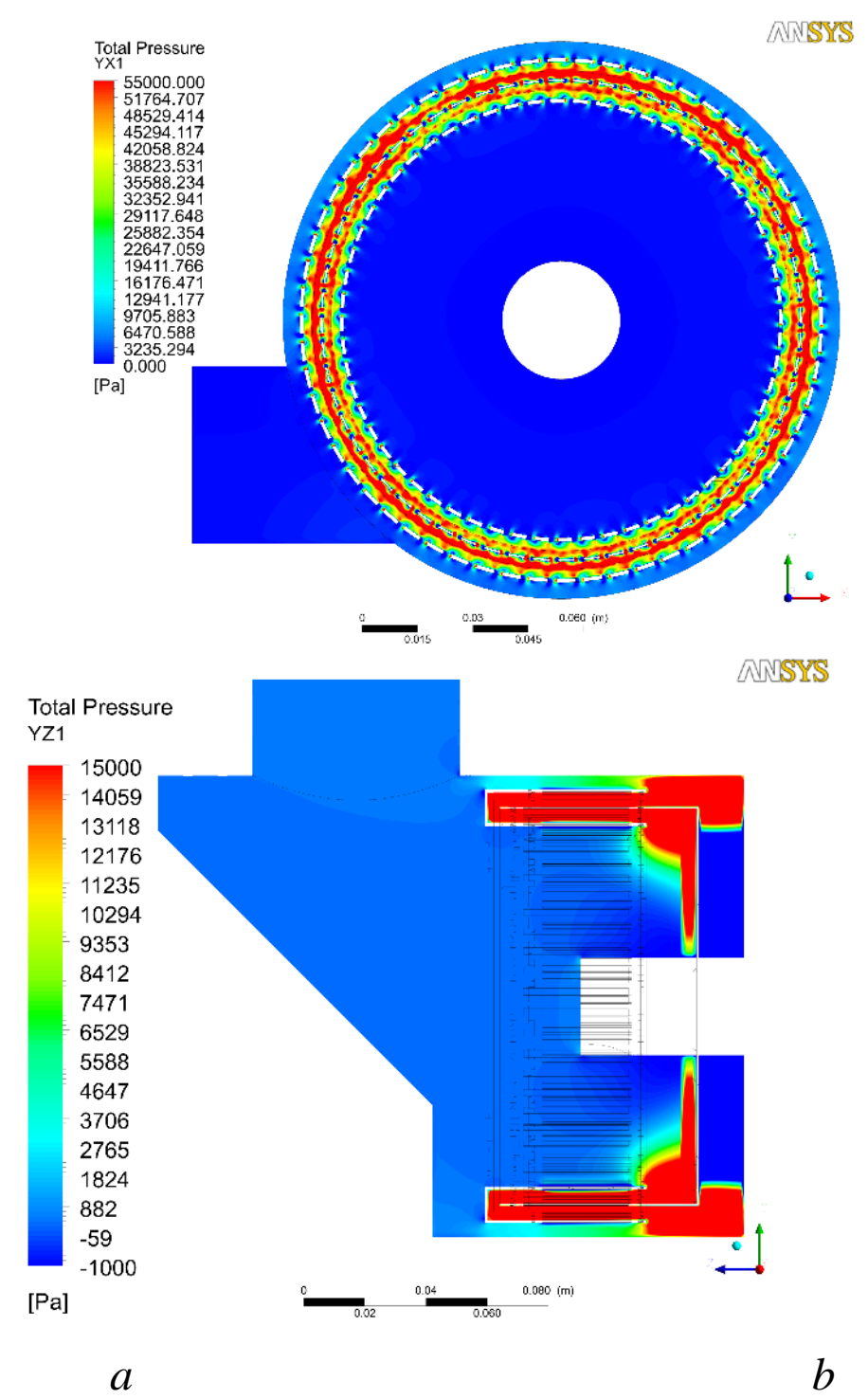

Fig. 2 Pressure distribution in the rotor-stator system:

$a$ - cross-section; $b$ - longitudinal section

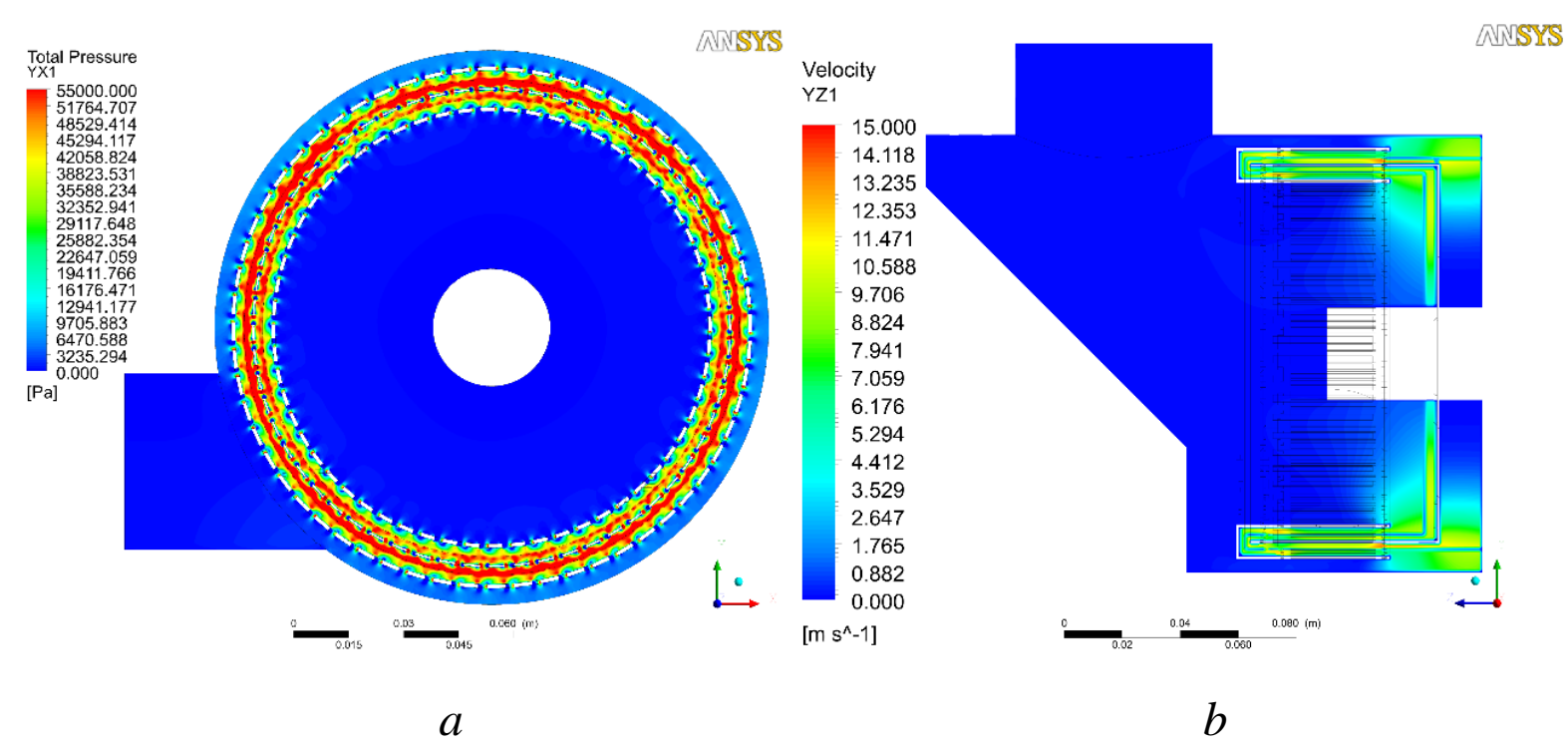

Fig. 3 Velocity distribution in the rotor-stator system: 


$$
a \text { - cross-section; } b \text { - longitudinal section }
$$

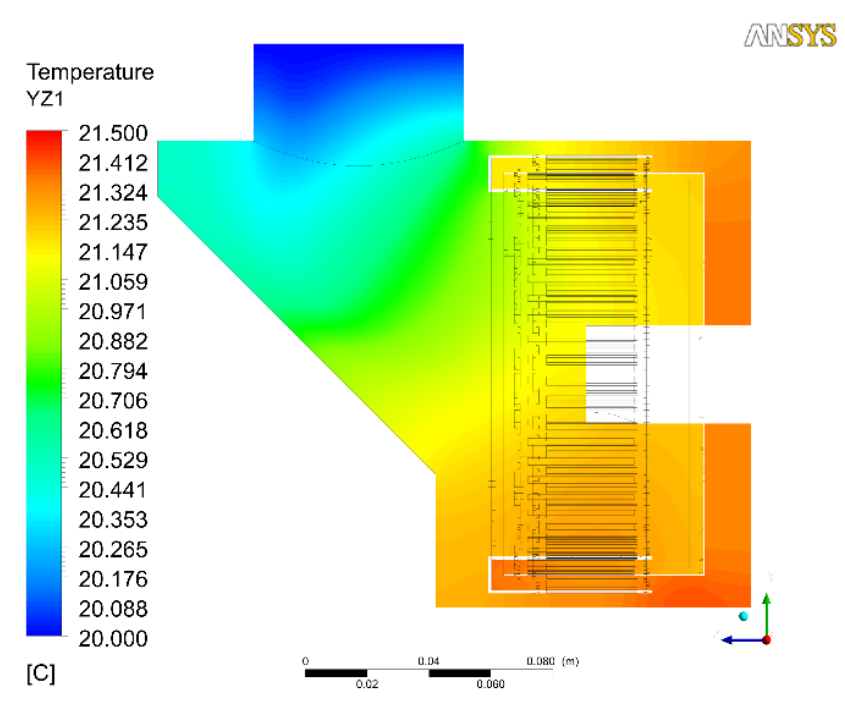

Fig. 4 Temperature distribution in the rotor stator system - longitudinal section

The analysis of the obtained results shows that in the RPA channels for the rotorstator system there is a significant increase in pressures and velocities in the areas near the surfaces of the rotor and stator. This is the turbulence of the flow of the liquid mixture, which is accompanied by dissipation of the kinetic energy of rotation of the rotor and the release of thermal energy, which increases the temperature of the mixture. Thus, when passing the feed through the holes in the rotor and stator produces a homogeneous mass of liquid feed with a higher temperature compared to the inlet temperature of the grain mixture.

Conclusions and Prospects. Numerical simulation of hydrodynamic and thermal processes in the channels of the rotary-pulsating apparatus for feed preparation with discrete-pulse energy supply using ANSYS Fluent software is carried out. Pressure and velocity distributions were obtained, indicating a significant increase in their values in the areas immediately adjacent to the rotor and stator surfaces. These processes are accompanied by the conversion of kinetic energy of rotation of the rotor into thermal energy, which leads to an increase in the temperature of the liquid feed mixture. 


\section{References}

1. Promtov M.A. (2004) Mashini i apparati s impulsnimi energetichkimi vozdeistviiami na obrabativaiemi veshestva (Machines and apparatus with impulsive energy effects on processable substances). Moskva. Mashinostroenie. 93.

2. Gorobets V.G., Geskin D.V. (2014) Dotsilnist vikoristannia rotornopulsatsijnogo aparatu dlia prigotuvania kormiv (Feasibility of using a rotary pulsating apparatus for the preparation of liquid feed). Scientific Bulletin of NULES of Ukraine. Kiev. № 194. Part 1. 45-50.

3. Dolinsky A.A., Basks B.I., Nakorchevsky A.I/, Shurchkova Yu.A. Diskretnoimpulsnij vvod energii (Discrete-impulse energy input). Kiev. ITTF NASU. 196.

4. Proc. International Conf. on Transport Phenomena Science and Technology. Dolinsky A. A. Use of discrete- pulse energy input in various production processes / A. A. Dolinsky, G. K. Ivanitsky - Beijing (China): Higher Education Press. 1992. - P. 89100

5. Obodovich A. N., Draganov B. Kh., Lymar A. Yu. (2013) Issledovanije protsessa dispergirovania zernivih smesej s primeneniem metoda diskretno-impulsnogo vvoda energii (DIVE) dlia polutshenija zhidkih kormov. (Investigations of the process of dispersion of grain mixtures using the method of discrete-impulse energy input (DIEI) to obtain liquid feed). Promishlennaia teploteknika. V. 35. N5. 9-18.

6. Schlichting, H. (1979) Boundary-Layer Theory. $7^{\text {th }}$ edition. McGraw-Hill. New York.

7. Taler, D. (2019) Numerical Modelling and Experimental Testing of Heat Exchangers. Springer, Berlin-Heildelberg.

8. ANSYS FLUENT Theory Guide. Release 14. ANSYS, Inc. Southpointe 275 Technology Drive Canonsburg, PA 15317, 2011.

\section{ЧИСЕЛЬНЕ МОДЕЛЮВАННЯ ПРОЦЕСІВ ГІДРОДИНАМІКИ І ТЕПЛОПЕРЕНОСУ В РОТОРНО-ПУЛЬСАЦИЙНОМУ АПАРАТІ ДЛЯ ПРИГОТУВАННЯ РІДКИХ КОРМІВ}

\section{В. Г. Горобець, В. І. Троханяк, А. М. Сердюк}

Анотація. Одним із актуальних напрямків розвитку агропромислового комплексу України є розвиток свинарської галузі тваринництва. Вирімальну роль відіграє процес годування тварин. Важливо розробити нові конструкиії пристроїв для приготування рідких кормів на основі зернових сумішей.

Метою дослідження $\epsilon$ чисельне вивчення прочесів гідродинаміки та теплопередачі у ротаційно-пульсуючому апараті при обробиі водно-зернової сумімі для приготування рідких кормів.

Проведено математичне моделювання проиесів гідродинаміки $i$ теплопереносу в каналах роторно-пульсаційного апарата для приготування рідких кормів. В результаті чисельного моделювання теплових і гідродинамічних процесів використовуючи програмний продукт ANSYS Fluent отримано розподіли швидкостей, тисків і температур в каналах системи ротор-статор. Знайдено перетворення кінетичної енергії обертання ротора в теплову енергію, щьо призводить до підвищення температур рідкої зернової сумімі. 
Ключові слова: роторно-пульсаційний апарат, канал, ротор, статор, тиск, швидкість, температура

ЧИСЛЕННОЕ МОДЕЛИРОВАНИЕ ПРОЦЕССОВ ГИДРОДИНАМИКИ И ТЕПЛОПЕРЕНОСА В РОТОРНО-ПУЛЬСАЦИОННОМ АППАРАТЕ ДЛЯ ПРИГОТОВЛЕНИЯ ЖИДКИХ КОРМОВ

\section{В. Г. Горобец, В. И. Троханяк, А. М. Сердюк}

Аннотация. Одним из актуальных направлений развития агропромышленного комплекса Украины является развитие свиноводческой отрасли животноводства. Решающую роль играет процесс кормления животных. Важно разработать новые конструкиии аппаратов для приготовления жидких кормов на основе зерновых смесей.

Целью исследования является численное исследование прочессов гидродинамики и теплообмена в роторно-пульсирующем аппарате при обработке водозернистой смеси для приготовления жидких кормов.

Проведено математическое моделирование проиессов гидродинамики и теплопереноса в каналах роторно-пульсачионного аппарата для приготовления жидких кормов. $B$ результате численного моделирования тепловых $u$ гидродинамических прочессов используя программный продукт ANSYS Fluent получены распределения скоростей, давлений и температур в каналах системы ротор-статор. Найдено преобразования кинетической энергии вращения ротора в тепловую энергию, что приводит к повыщению температур жидкой зерновой смеси.

Ключевые слова: роторно-пульсационный аппарат, канал, ротор, статор, давление, скорость, температур 